\title{
ORAL LESIONS IN KIDNEY TRANSPLANT RECIPIENTS
}

\author{
Katarina Levarda-Hudolin ${ }^{1}$, Tvrtko Hudolin², Nikolina Bašić-Jukić ${ }^{3}$ and Željko Kaštelan ${ }^{2}$ \\ ${ }^{1}$ Dr. Katarina Levarda-Hudolin Dental Practice; ${ }^{2}$ Clinical Department of Urology, ${ }^{3}$ Department of Nephrology, \\ Arterial Hypertension, Dialysis and Transplantation, Zagreb University Hospital Center, Zagreb, Croatia
}

\begin{abstract}
SUMMARY - Permanent immunosuppression is necessary to prevent rejection after kidney transplantation. However, it may predispose patients to different conditions and diseases including oral lesions. The most common benign oral lesions in kidney transplant recipients are gingival hyperplasia, oral candidiasis, hairy leukoplakia and saburral tongue. Oral form of Kaposi sarcoma, although rarely, can also be seen in kidney transplant patients. In this review, we present the incidence, etiology, clinical findings, diagnosis and treatment options for these lesions. For kidney transplant recipients, it is important to maintain good oral hygiene and care, as well as regular professional control by the dentist. This approach can reduce the number and severity of oral lesions.
\end{abstract}

Key words: Kidney transplantation; Mouth diseases; Gingival hyperplasia; Candidiasis, oral; Leukoplakia, hairy; Tongue, hairy; Sarcoma, Kaposi

\section{Introduction}

Kidney transplantation (KT) is the treatment of choice for patients with end-stage renal disease. It is the most cost-effective and improving quality of life strategy. In the last 20 years, the number of KT has increased, with more than 13000 cases in the United States of America (USA) ${ }^{1}$ and more than 200 cases in Croatia per year (208 KT in 2013) $)^{1}$. Due to improvement in patient selection, kidney preservation, immunosuppression, surgical techniques, diagnosis and treatment of complications, as well as in follow up, survival of grafts and KT patients has been significantly improved. In the USA, one-year kidney graft survival is $80 \%-85 \%$ for cadaveric and more than $90 \%$ for living donor transplants ${ }^{2}$.

Kidney allograft recipients usually have significant comorbidities, have been exposed to dialysis for longer period of time, and demand permanent immunosuppression. Therefore, they are liable to different diseases including oral lesions. In this review, we present the

Correspondence to: Katarina Levarda-Hudolin, DMD, Dr. Katarina Levarda-Hudolin Dental Practice, Gračanska cesta 189, HR10000 Zagreb, Croatia

E-mail: katarinalevardahudolin@gmail.com

Received April 3, 2013, accepted March 15, 2016 most common benign oral diseases in KT recipients and oral form of Kaposi sarcoma.

\section{Gingival Hyperplasia}

Gingival hyperplasia $(\mathrm{GH})$ or gingival overgrowth is a well known side effect of cyclosporine, calcium channel blockers such as nifedipine and anticonvulsants $^{3,4}$. The reported incidence of drug induced $\mathrm{GH}$ varies from $8 \%$ to $85 \%$, depending on the study population and methodology $y^{3,5}$. Although the mechanism of drug-induced $\mathrm{GH}$ remains unknown and probably is multifactorial, recent studies show that cyclosporine promotes $\mathrm{GH}$, affecting different signaling molecules in gingival fibroblasts ${ }^{6}$. Calcium channel blockers change calcium ion flux which may influence collagenase, resulting in changes in collagen production and breakdown in gingival fibroblast, leading to collagen deposition in gingival tissue ${ }^{7,8}$. In humans, there is no proven connection between $\mathrm{GH}$ and patient sex, diagnosis before transplantation, dialysis, age at transplantation or time after transplantation, but it has been shown that cyclosporine dose and plasma level were significant risk factors for development and extent of $\mathrm{GH}$. Also, gingival inflammation and tooth plaque 
were strongly associated with $\mathrm{GH}^{9}$. Children and adolescents are more prone to this disease than adults ${ }^{10}$, and it is important to note that the patients developing severe $\mathrm{GH}$ had evidence of $\mathrm{GH}$ prior to kidney transplantation ${ }^{11}$.

Gingival hyperplasia or gum status can be scored in three or, better, four grades: grade 0 (normal gum); grade 1 or mild GH (slight overgrowth and thickening of marginal gum, covering up to $1 / 3$ of the crown); grade 2 or moderate $\mathrm{GH}$ (moderate gum overgrowth covering $1 / 2$ of the crown), which is the most common form; and grade 3 or severe GH (severe gum overgrowth covering $2 / 3$ of the crown, or affecting all of adhered gum $)^{12}$. The most affected are usually labial aspects of both superior and inferior anterior teeth ${ }^{13}$. At the beginning of disease, interdental papillae become soft, red nodules which can easily bleed. Progressive hyperplasia extends to labial, buccal, palatal and lingual gingiva, later due to fibrotic changes the tissue appears pink, firm and resilient to palpation. In most severe cases, almost whole crown can be covered with gum tissue. GH can be painful; it can cause difficulties on eating and speaking, as well as aesthetic problems.

Although withdrawal of therapy would be the best option, it is usually not possible in KT recipient. However, switching from cyclosporine to the newer immunosuppressive drug tacrolimus can lead to regression or complete resolution of $\mathrm{GH}^{14}$. Also, in patients having used tacrolimus from the beginning $\mathrm{GH}$ was present only sporadically ${ }^{15}$. Complete resolution of GH has been shown in adult KT recipients that have been treated with metronidazole ${ }^{16}$, but these results were not confirmed in pediatric population ${ }^{17}$. The treatment with azithromycin also showed significant improvement of $\mathrm{GH}$ in $\mathrm{KT}$ recipients ${ }^{18}$. The exact mechanisms how these drugs effect $\mathrm{GH}$ is not known, but they are probably related to their antimicrobial effect. Hyperplastic tissue can also be surgically removed, either by traditional gingivectomy or using laser as a newer, less invasive procedure ${ }^{19}$. Good oral hygiene and oral chlorhexidine rinse can be helpful for $\mathrm{GH}$, mainly due to reduction in gingival inflammation and plaque removal ${ }^{20}$.

\section{Oral Candidiasis}

Candida albicans may be present in normal oral flora in up to $50 \%$ of the population. It is the most common cause of oral candidiasis (70\%-80\%), although other Candida species such as Candida glabrata and Candida tropicalis can cause this disease as well ${ }^{21}$. Diseases or conditions like immunosuppression, which affect the host immune system, predispose patients to candida infections. Furthermore, immunosuppression is the most important factor for development and progression of oral candidiasis. In KT patients, Candida dubliniensis and Candida famata cause a significant number of cases ${ }^{7,22}$. The reported incidence of oral candidiasis in KT recipients varies from $4 \%$ to $43 \%{ }^{23-25}$. Most commonly infected are the palate, tongue and buccal mucosa, although any oral mucosal surface can be involved. There are different clinical presentations of the disease, with erythematous, pseudomembranous and hyperplastic candidiasis being the most common types ${ }^{26}$. Erythematous candidiasis can be categorized into acute and chronic atrophic, angular cheilitis, median rhomboid glossitis and chronic multifocal candidiasis. Erythematous candidiasis is presented with erythema of the involved tissue, although atrophic changes and fissures can be seen as well. Pseudomembranous candidiasis is characterized with white-yellow plaques that can be wiped off revealing underlying mucosa with erythematous appearance which may bleed slightly. This form of candidiasis is most common in immunocompromised patients. Hyperplastic candidiasis or candidal leukoplakia is presented as white lesions, most commonly on buccal mucosa, although occasionally focal areas of erythema can be seen ${ }^{26}$.

Diagnosis is usually based on clinical presentation and patients are often empirically treated with antifungal medication. To confirm the disease, laboratory testing of clinical specimens have to be done. Samples from suspected areas can be obtained for culture using Sabouraud's agar plate, for exfoliative cytology or biopsy. On microscopy, candida hyphae or blastospores can be seen. For prevention and treatment of the disease, regular oral hygiene is mandatory. Rinsing of oral cavity with $0.1 \%$ hypochlorite or chlorhexidine solution is advisable ${ }^{27}$. Antifungal drugs such as nystatin can be applied topically or systemic therapy with fluconazole or itraconazole can also be used.

\section{Saburral Tongue}

Saburral tongue is clinically presented as a yellowish-white superficial layer on the back of the tongue, 
resembling pseudomembranous candidiasis, but cannot be scraped off. Filiform papillae enlargement can also be seen. In the study by de la Rosa Garcia et al., suburral tongue was found in $22 \%$ of patients with $\mathrm{KT}^{28}$. The etiology of this condition is unknown, although some authors report on the association between suburral tongue and poor oral hygiene ${ }^{29}$. Furthermore, the accumulation of anaerobic bacteria in the subgingival plaque has been shown, suggesting that they may be important for this condition.

\section{Hairy Leukoplakia}

Leukoplakia is defined as a white adherent patch or plaque that can occur on oral mucosa. Oral hairy leukoplakia is a form of leukoplakia which presents as a white, hairy appearing lesion on one or both lateral borders of the tongue, which cannot be scraped off. It may also extend to buccal, labial or palatal mucosa. This condition is related to immune status and most patients are immunocompromised ${ }^{30}$. Hairy leukoplakia can be seen in $8 \%-11 \%$ of patients with $\mathrm{KT}^{7,31}$. Histologically, severe hyperkeratosis and acanthosis with virally infected epithelial cells can be seen. Epstein-Barr virus was isolated from these cells and has been implicated as a causative factor for hairy leukoplakia ${ }^{32}$. Candida albicans can also be related to this lesion. Hairy leukoplakia is usually asymptomatic and has no malignant potential, therefore, no treatment is needed in most cases. However, antiviral medication such as acyclovir or gancyclovir, topical podophyllin or even surgical excision can be used, although recurrence is common as long as the cause of immunosuppression is present ${ }^{32}$.

\section{Kaposi Sarcoma}

Kidney transplant recipients have a significantly higher frequency of malignant lesions as compared with general population and the risk is increasing with each year after transplantation. Kaposi sarcoma accounts for $5.7 \%-11 \%$ of all neoplasms arising after $\mathrm{KT}^{33,34}$. It is an angiogenic tumor the development of which can be divided into three phases, i.e. the patch or macular stage, the plaque, and the nodular stage ${ }^{35}$. Histopathologically, the disease is characterized by endothelium-lined vascular spaces and spindle-shaped cells $^{36}$. Kaposi sarcoma can be seen as oral lesion (pal- ate and gingiva) after renal transplantation, and it is important to know that in oral presentation, Kaposi sarcoma may mimic gingival hyperplasia. The etiology of the disease is unknown, although Kaposi sarcoma has been strongly related to immunosuppression and human herpes virus $8^{37}$. The disease is usually asymptomatic, although the lesion itself can be seen in the mouth. In KT patients with Kaposi sarcoma, immunosuppression with cyclosporine and mycophenolate mofetil should be replaced with an mTOR inhibitor (sirolimus or everolimus), and the disease can be treated with surgery, irradiation and chemotherapy (paclitaxel $)^{38}$.

\section{Discussion and Conclusion}

Approximately two-thirds of KT patients have at least one oral mucosa lesion ${ }^{28}$. The most common oral mucosa lesions that can be found after thorough oral examination of renal transplant recipients are gingival hyperplasia, oral candidiasis, hairy leukoplakia and saburral tongue ${ }^{39}$. All these lesions can be related to immunosuppressive drugs, either as their side effect or as a direct consequence of the patient immune status. The most common drugs used for immunosuppression after KT are calcineurin inhibitors (cyclosporine and tacrolimus), steroids, mycophenolate mofetil and mTOR inhibitors (mammalian target of rapamycin).

For KT patients, good oral hygiene and care, regular professional control by the dentist, as well as optimal treatment for different oral lesions including change of immunosuppressive therapy when necessary, can reduce the number and severity of oral lesions.

Oral health is not only important for KT patients, but also for general population. It has recently been shown that different chronic oral conditions such as periodontitis can be related to different systemic diseases, e.g., anemia of chronic disease ${ }^{40}$. Posttransplant anemia is a chronic condition related to erythropoietin substitution and blood transfusion. Investigation of oral status in KT patients with anemia may give additional data on the possible link between oral diseases and chronic diseases such as anemia ${ }^{41}$.

\section{References}

1. http://www.zdravlje.hr/programi_i_projekti/transplantacijski_ program/statistika. STATISTIKA - 2013. Preliminarno izvješće 2013. (in Croatian) 
2. Bretan PN Jr. Renal transplantation. Urinary stone disease. In: Tanagho EA, McAninch JW, editors. Smith's General Urology. $16^{\text {th }}$ ed. New York: Lang Medical Books/McGrawHill, 2004; p. 546-59.

3. Lima RB, Benini V, Sens YA. Gingival overgrowth in renal transplant recipients: a study concerning prevalence, severity, periodontal and predisposing factors. Transplant Proc. 2008;40: 1425-8. http://dx.doi.org/10.1016/j.transproceed.2008.01.071

4. Thomason JM, Seymour RA, Ellis JS, et al. Iatrogenic gingival overgrowth in cardiac transplantation. J Periodontol. 1995; 66:742-6. http://dx.doi.org/10.1902/jop.1995.66.8.742

5. Allman SD, McWhorter AG, Seale NS. Evaluation of cyclosporine-induced gingival overgrowth in the pediatric transplant patient. Pediatr Dent. 1994;16:36-40.

6. Bostrom A, Bharath H, Saulewicz A, et al. Cyclosporin A affects signaling events differentially in human gingival fibroblast. J Dent Res. 2005;84:532-6. http://dx.doi.org/10.1177/ 154405910508400609

7. Al-Mohaya MA, Darwazeh AMG, Bin-Salih S, et al. Oral lesion in Saudi renal transplant patients. Saudi J Kidney Dis Transplant. 2009;20:20-9.

8. Hood KA. Drug-induced gingival hyperplasia in transplant recipients. Prog Transplant. 2002;12:17-21. http://dx.doi.org/ 10.7182/prtr.12.1.k0605089820vt807

9. Thomas DW, Newcombe RG, Osborne GR. Risk factors in the development of cyclosporine-induced gingival overgrowth. Transplantation. 2000;69:522-6. http://dx.doi.org/10.1097/ 00007890-200002270-00010

10. Hefti AF, Eshenaur AE, Hassell TM, et al. Gingival overgrowth in cyclosporine A treated multiple sclerosis patients. J Periodontol. 1994;65:744-9. http://dx.doi.org/10.1902/jop. 1994.65.8.744

11. Varga E, Lennon MA, Mair LH. Pre-transplant gingival hyperplasia predicts severe cyclosporine-induced gingival overgrowth in renal transplant patients. J Clin Periodontol. 1998;25:225-30. http://dx.doi.org/10.1111/j.1600-051x.1998. tb02432.x

12. Pernu HE, Pernu LMH, Huttunen KRH. Gingival overgrowth among renal transplant recipients related to immunosuppressive medication and possible local background factors. J Periodontol. 1992;63:548-53. http://dx.doi.org/10.1902/jop. 1992.63.6.548

13. Thomason JM, Kelly P, Seymour RA. The distribution of gingival overgrowth in organ transplant patients. J Clin Periodontol. 1996;23:367-71. http://dx.doi.org/10.1111/j.1600-051x.1996. tb00559.x

14. Thorp M, DeMattos A, Bennett W, et al. The effect of conversion from cyclosporine to tacrolimus on gingival hyperplasia, hirsutism and cholesterol. Transplantation. 2000;69;1218-20. http://dx.doi.org/10.1097/00007890-200003270-00029

15. Adams CK, Famili PA. Study of the effects of the drug FK506 on gingival tissues. Transplant Proc. 1991;23:3193-4.
16. Wong W, Hodge MG, Lewis A, et al. Resolution of cyclosporine-induced gingival hypertrophy with metronidazole. Lancet. 1994;343:986. http://dx.doi.org/10.1016/s0140-6736 (94)90115-5

17. Aufricht C, Hogan EL, Ettenger RB. Oral metronidazole does not improve cyclosporine $\mathrm{A}$-induced gingival hyperplasia. Pediatr Nephrol. 1997;11:552-5. http://dx.doi.org/10.1007/ s004670050336

18. Nash MM, Zaltzman JS. Efficacy of azithromycin in the treatment of cyclosporine-induced gingival hyperplasia in renal transplant recipients. Transplantation. 1998;65:1611-5. http:// dx.doi.org/10.1097/00007890-199806270-00012

19. Mattson JS, Blankenau R, Keene JJ. Case report. Use of an argon laser to treat drug-induced gingival overgrowth. J Am Dent Assoc. 1998;129:78-83. http://dx.doi.org/10.14219/jada. archive.1998.0024

20. O'Neil TC, Figures KH. The effects of chlorhexidine and mechanical methods of plaque control on the recurrence of gingival hyperplasia in young patients taking phenytoin. Br Dent J. 1982;152:130-3. http://dx.doi.org/10.1038/sj.bdj. 4804760

21. Vazquez JA, Sobel JD. Mucosal candidiasis. Infect Dis Clin North Am. 2002;16:793-820. http://dx.doi.org/10.1016/ s0891-5520(02)00042-9

22. McCullough MJ, Ross BC, Reade PC. Candida albicans: a review of its history, taxonomy, epidemiology, virulence attributes, and methods of strain differentiation. Int J Oral Maxillofac Surg. 1996:25:136-44. http://dx.doi.org/10.1016/s09015027(96)80060-9

23. Greenberg MS, Cohen G. Oral infection in immunosuppressed renal transplant patients. Oral Surg Oral Med Oral Pathol. 1977;43:879-85. http://dx.doi.org/10.1016/0030-4220 (77)90080-9

24. Gupta KL, Ghosh AK, Kochhar R, et al. Esophageal candidiasis after renal transplantation: comparative study in patients on different immunosuppressive protocols. Am J Gastroenterol. 1994;89:1062-5.

25. López-Pintor RM, Hernández G, de Arriba L, et al. Oral candidiasis in patients with renal transplants. Med Oral Patol Oral Cir Bucal. 2013;18:381-7. http://dx.doi.org/10.4317/medoral.18658

26. Giannini PJ, Shetty KV. Diagnosis and management of oral candidiasis. Otolaryngol Clin North Am. 2011;44:231-40. http://dx.doi.org/10.1016/j.otc.2010.09.010

27. Farah CS, Ashman RB, Challacombe SJ. Oral candidosis. Clin Dermatol. 2000;18:553-62. http://dx.doi.org/10.1016/s0738081x(00)00145-0

28. de la Rosa Garcia E, Mondragon Padilla A, Irigoyen Camacho $\mathrm{ME}$, et al. Oral lesions in a group of kidney transplant patients. Med Oral Patol Oral Cir Bucal. 2005;10:196-204.

29. Avcu N, Kanli A. The prevalence of tongue lesions in 5150 Turkish dental outpatients. Oral Dis. 2003;9:188-95. http:// dx.doi.org/10.1034/j.1601-0825.2003.02933.x

30. Triantos D, Porter SR, Scully C, et al. Oral hairy leukoplakia: clinicopathologic features, pathogenesis, diagnosis and clinical 
significance. Clin Infect Dis. 1997;25:1392-6. http://dx.doi. org/10.1086/516131

31. King GN, Healy CM, Glover MT, et al. Prevalence and risk factors associated with leukoplakia, hairy leukoplakia, erythematous candidiasis and gingival hyperplasia in renal transplant recipients. Oral Surg Oral Med Oral Pathol. 1994;78:718-26. http://dx.doi.org/10.1016/0030-4220(94)90086-8

32. Bhattacharyya I, Chehal HK. White lesions. Otolaryngol Clin North Am. 2011;44:109-31. http://dx.doi.org/10.1016/j. otc.2010.09.009

33. Penn I. Kaposi's sarcoma in transplant recipients. Transplantation. 1997;64:669-73. http://dx.doi.org/10.1097/00007890199709150-00001

34. Bubić-Filipi Lj, Bašić-Jukić N, Pasini J, et al. Clinical features of Kaposi's sarcoma in Croatian renal transplant recipients. Prilozi. 2009;30:175-84.

35. Neville BW, Damm DD, Allen CM, Bouquot JE. Soft tissue tumors. In: Neville BW, Damm DD, Allen CM, Bauquot JE, editors. Oral and Maxillofacial Pathology. $2^{\text {nd }}$ ed. Philadelphia: W.B.Saunders Company; 2002; p. 484-6.
36. Taheri S, Afsharmoghadam N, Berjis N, et al. Solitary laryngeal Kaposi sarcoma in a kidney transplant patient. Iran J Kidney Dis. 2012;6:222-4.

37. Darling M, Thompson I, Meer M. Oral Kaposi's sarcoma in renal transplant patients: case report and literature review. J Can Dent Assoc. 2004;70:617-20.

38. Patel N, Salifu M, Sumrani N, et al. Successful treatment of post-renal transplant Kaposi's sarcoma with paclitaxel. Am J Transplant. 2002;2:877-9. http://dx.doi.org/10.1034/j.1600$-6143.2002 .20911 . x$

39. Popovska M, Spasovski G, Orovčanec N, et al. Oral findings in end-stage renal disease. Prilozi. 2013;34:85-92.

40. Patel MD, Shakir QI, Shetty A. Interrelationship between chronic periodontitis and anemia: a 6-month follow-up study. J Indian Soc Periodontol. 2014;18:19-25. http://dx.doi.org/ 10.4103/0972-124x.128194

41. Banjeglav J, Zibar L. Posttransplantation anemia 6 months after kidney transplantation. Acta Med Croatica. 2012;66 (Suppl 2):4-11.

Sažetak

\section{PROMJENE U USNOJ ŠUPLJINI NAKON TRANSPLANTACIJE BUBREGA}

\section{K. Levarda-Hudolin, T. Hudolin, N. Bašić-Jukić i Ž. Kaštelan}

Nakon transplantacije bubrega bolesnici moraju biti na trajnoj imunosupresiji, što ih čini osjetljivima za različita stanja i bolesti uključujući oralne lezije. Najčešće dobroćudne oralne lezije kod bolesnika s transplantiranim bubregom su hiperplazija gingive, oralna kandidijaza, vlasasta leukoplakija i obloženi jezik. Oralna forma Kaposijevog sarkoma također se, iako rijetko, može vidjeti kod bolesnika s transplantiranim bubregom. Donosimo pregled incidencije, etiologije, kliničke slike, dijagnoze i liječenja ovih lezija. Kod bolesnika s transplantiranim bubregom važna je redovita skrb za oralno zdravlje uz održavanje oralne higijene te redovite posjete liječnicima dentalne medicine, što sve može smanjiti broj i ozbiljnost oralnih lezija.

Ključne riječi: Bubreg, transplantacija; Oralne bolesti; Gingivalna hiperplazija; Kandidijaza, oralna; Leukoplakija, vlasasta; Jezik, obloženi; Sarkom, Kaposijev 